\title{
Os Dias Secretos de Orson Welles no Brasil: variação textual e mudança de endereçamento
}

\author{
Edina Regina Pugas PANICHI* \\ Lívia Sprizão de OLIVEIRA**
}

* Pós-Doutora em Teoria e Crítica Literária pela Universidade Federal de Minas Gerais (UFMG). Professora Sênior na Universidade Estadual de Londrina (UEL). Contato: edinapanichi@sercomtel.com.br.

** Mestre (2017) e Doutoranda em Estudos da Linguagem pela Universidade Estadual de Londrina (UEL). Contato: liviaoliveiratv@gmail.com.

\section{Resumo:}

A construção textual é um movimento dinâmico de prospecções e retrospecções, em que o escritor materializa suas ideias num contínuo de escolhas e intenções variáveis a partir da releitura da própria escrita. Notas pré-redacionais e rascunhos são documentos memoriais do fazer artístico em busca da singularidade da obra por meio de um estilo de gênese, um ritmo individual que dá forma à escritura. Neste trabalho nos valemos de conceitos da Estilística somados aos fundamentos da Crítica Genética para analisar a cena de abertura da peça Eterno, de Doc Comparato, a partir de um conjunto de documentos de processo. Observamos a variação textual, desde as primeiras notas até a publicação, além da metamorfose para o roteiro cinematográfico intitulado Os dias secretos de Orson Welles no Brasil. Selecionamos sete manuscritos (de um total de duzentos), e organizamos o prototexto da Cena do ovo selvagem. Identificamos registros da elaboração do estilo da obra, que podem ser visualizados nos atos de rejeitar e selecionar recursos de linguagem, além de práticas no desenvolvimento da escrita que se repetem em outros trabalhos do autor e podem indicar a marca individual de Comparato.

\section{Palavras-chave:}

Crítica Genática. Dramaturgia. Criação textual.

Signum: Estudos da Linguagem, Londrina, v. 23, n. 2, p. 56-71, ago. 2020 


\section{Os Dias Secretos de Orson Welles no Brasil: variação textual e mudança de endereçamento ${ }^{1}$}

Edina Regina Pugas Panichi; Lívia Sprizão de Oliveira

\section{INTRODUÇÃo}

No fazer artístico, a criação reflete a necessidade da expressão do imaginário, transcendendo a busca pela imortalidade por meio da obra. O escritor costura uma rede de informações com a língua, trazendo para o concreto memórias e imagens mentais. Na peneira da escritura, movimentos entendidos como equívocos, devaneios ou intuições que falharam são eliminados da composição final. Mas fazem parte do processo de criação, dos pequenos passos ou etapas que resultam na "descoberta". O texto final é publicado "sem mácula", o que não significa que tenha nascido assim. A Crítica Genética pretende recuperar justamente o caminho de tentativas, correções e ajustes no curso da escrita.

As crises do autor ao longo desse trajeto, as pausas e os remanejamentos, podem ser as chaves para explicar como a "inspiração" pode ser composta de uma série de repostas a "perguntas-problemas". É também ao longo do processo de escolhas, do contínuo de intencionalidades e intuições que se dá a singularização da identidade da obra. Há um movimento de prospecção e retrospecção em que o escritor registra suas ideias, lê suas notas e rascunhos, volta a escrever, lê a si mesmo e se reescreve, construindo formas intimamente relacionadas com o que lhe agrada ou com o que desaprova.

Salles (2006, p. 23) afirma que para o geneticista "os atos de rejeitar, adequar ou reaproveitar são permeados por critérios, que nos interessam conhecer, e refletem modos de desenvolvimento de pensamento, que nos instigam a compreender, descrever e nomear". A investigadora confere à criação um aspecto de rede, onde há conectividade entre diversos elementos: "a criação alimenta-se e troca informações com seu entorno em sentido bastante amplo" (p. 32).

Utilizando fundamentos da Crítica Genética e Estilística, analisamos neste artigo o processo de composição da Cena do ovo selvagem, que abre a peça Eterno/Xanadu, no limite da criatividade/No inalcançável das coisas, o primeiro texto da Trilogia da Imaginação, do dramaturgo carioca Doc Comparato. Partimos de um acervo de documentos coletados, uma espécie de inventário do processo de criação, e montamos o dossiê genético composto por fólios organizados e classificados. Dessa matéria-prima foi elaborado o prototexto, um ordenamento crítico do material de análise.

Nosso dossiê genético é composto por duzentos fólios, além de elementos complementares tais como registros da biblioteca pessoal do autor, entrevistas publicadas em jornais, revistas e outros meios de comunicação, entrevistas exclusivas para esta pesquisa, e o conjunto de obras de Comparato. Para o presente trabalho fizemos um recorte composto por sete fólios manuscritos, sendo que dois contêm notas da fase pré-redacional e cinco são rascunhos da fase redacional.

Mantivemos como referência da análise a versão final do texto teatral, publicada pelo autor, entendendo que os manuscritos não podem ser lidos como textos independentes. Não almejamos recriar a

${ }^{1}$ Este trabalho foi realizado com apoio da Coordenação de Aperfeiçoamento de Pessoal de Nível Superior - Brasil (CAPES). 
obra, mas estabelecer relações entre o que há de concreto no percurso de criação e a singularização da linguagem, a construção da identidade da obra. Observando as operações gráficas (rasuras, anotações nas margens, sobrescritas, flechas, riscos e indicações) e modificações enunciativas (acréscimos, supressões e substituições), buscamos identificar marcas do fazer artístico do autor, sua tendência de ritmo e preferências.

Também observamos a metamorfose de formatos textuais a partir da mudança de endereçamento. Doc Comparato transforma o texto teatral em roteiro cinematográfico, fazendo com que o fim de um processo seja gênese de outro, em movimento contínuo. A variação entre formatos também é feita de acréscimos, supressões e mudanças enunciativas visando outro objetivo comunicacional, outro destinatário. Acompanhamos as metamorfoses da Cena do ovo selvagem, da fase pré-redacional até a versão final do texto para teatro, e a nova transformação para roteiro cinematográfico.

\section{Gênese e Movimento Criador}

Encontrar a palavra que melhor expressa um universo subjetivo, fechar as conexões entre as ideias, dar forma ao texto ou encontrar o tempo dramático para uma cena podem ser momentos extremamente prazerosos, após um período de tensão criativa. Para o escritor é o momento divino de contemplar a obra e avaliar se está tudo perfeito. Entretanto, os momentos de gozo não estão restritos à finalização do trabalho, mas a cada ato de reler, refazer, encontrar a medida exata. Para Willemart (2009), a rasura é a porta da criação:

Se cada rasura marca uma parada na escritura, é porque algo chamou a atenção do scriptor. Pode ser a lembrança de uma informação, um sonho, a palavra de um próximo, uma ideia a respeito da trama ou das personagens, algo desconhecido ou uma associação (p. 103).

A conexão entre diferentes memórias do autor alimenta a criação. Conhecimentos técnicos ou enciclopédicos, pesquisas direcionadas, relacionamentos interpessoais, observação da natureza, das coisas, conversas de rua, eventos que ficam retidos na memória sensível são informações que compõem um repertório a ser acessado de forma dinâmica e que podem se ligar de maneiras imprevisíveis.

$\mathrm{Na}$ composição dos textos da Trilogia da Imaginação, percebemos que Comparato nutriu-se de várias camadas de informações que incluem: 1) Pesquisa histórica e bibliográfica; 2) Pesquisa audiovisual; 3) Resgate de memórias e guardados pessoais; 4) Imaginação e criação metafórica de fatos. Os rascunhos revelam remissões a algumas fontes e um movimento de transformação dessas referências em outras formas redacionais. Notas aleatórias funcionam como uma porta de acesso à essência da escritura.

Ferrer (1994) ressalta, entretanto, que os documentos de processo de um escritor não têm uma intenção comunicacional, uma vez que o destinatário é o próprio autor. "Na medida em que são documentos preparatórios para um ou mais trabalhos futuros, eles não têm lógica própria” (p. 46). Assim, não devemos considerar o dossiê genético, nem o prototexto (ou avant-texte), um texto em si, mas um contíguo contextual e memorial de uma ideia criadora. A criação guarda nos rascunhos memórias de seus traços.

A Crítica Genética observa as metamorfoses do texto, recuperando a atuação do autor no processo de ordenação da escritura e instaurando a instância do escrevente, que Willemart (2009) denomina scriptor, influenciado por elementos e intenções conscientes e inconscientes, estratégias de sedução e tomadas de decisão. Assim, além de reunir fundamentos de análise, também potencializa ser uma ciência da criação textual e artística.

A aplicação dos fundamentos da Crítica Genética à leitura do texto resgata, essencialmente, o autor e seu trabalho de criação. Percebemos, ao longo da observação dos processos criativos, que o meio não 
oferece respostas às ações, ao contrário, é o escritor quem seleciona informações e palavras, partindo das próprias vivências e habilidades de execução. Ele é impelido a fazer escolhas e a testá-las em um jogo de experimentação que provoca a relação entre intenção e a busca de um efeito, utilizando-se de fontes conscientes e inconscientes.

A Estilística se encarrega de estudar os efeitos expressivos gerados pelas escolhas do autor, burilados ao longo da construção do conteúdo, obedecendo uma relação entre signos, aquilo que denotam e aquilo que se pode inferir a partir de sua força ilocucionária. Conforme Monteiro (1991, p. 17), "a característica fundamental da expressividade reside na ênfase, na força de persuadir ou transmitir os conteúdos desejados, na capacidade apelativa, no poder de gerar elementos evocatórios ou conotações".

Comparato utiliza várias estratégias estilísticas que nos permitem acompanhar os critérios de suas escolhas. A sua forma de moldar e esculpir o texto demonstra, muitas vezes, um tom vacilante, de quem propõe tentativas se autocorrigindo e testando possibilidades. Os documentos de processo deixados pelo autor são testemunhas da plasticidade do raciocínio em seu caminho rumo à criação e, tomados em conjunto, revelam a intensa busca do artista em recompor criativamente a realidade.

Adotamos esse caminho literário-genético para investigar a expressividade do indivíduo e seu fazer artístico, as marcas do autor na escritura, dentro do contexto da criação. Ao observar as pausas e refacções em busca de uma forma de dizer, queremos encontrar o que Alonso (1969) chamou de gozo estético, a tensão e o prazer do escritor na busca pelo efeito expressivo. Chegamos ao que Pierrot (2005) chama de "estilo em movimento" para buscar o imbricamento entre o estilo de gênese do autor e os gestos que culminam na singularização da obra.

Para Reynaud (2000, p. 108) "O texto de ficção deve ser visto principalmente como comunicação, e o acto de leitura essencialmente como uma relação dialógica". Considerando esse pressuposto, observar a relação entre as expressões enunciativas do autor e as escolhas entre os recursos linguísticos que as acompanham, podem nos levar a pressupor que alguns efeitos expressivos são mais prováveis que outros, dentro do contexto.

Conforme Ostrower (2008, p. 11) "o ato criador não nos parece existir antes ou fora do ato intencional, nem haveria condições, fora da intencionalidade, de se avaliar situações novas ou buscar novas coerências". O escritor estabelece critérios e, mesmo quando guiado pela intuição, busca ao longo do fazer artístico tomar consciência de seus desejos enquanto os expressa e experimenta dar-lhes forma. O uso intencional da linguagem envolve a escolha de lexemas de acordo com o que se pressupõe sobre sua carga semântica, assim como a ordenação dos enunciados em função do desejo de expressar estados psíquicos, emotivos ou intelectuais. Essa intencionalidade é contínua e pode ser redefinida à medida que a construção da obra avança.

\section{Dramaturgia e Gênese Criativa}

O principal elemento do texto dramatúrgico é sua capacidade de alçar a encenação. Portanto, as estratégias de escrita estão voltadas para uma composição que precisa prever o que será visto e ouvido. Independentemente do uso que se fará do texto, contemporaneamente ou em um futuro incerto, as palavras precisam estar prontas para a ação, para a dramatização.

Enquanto padrão, podemos reconhecer nesse gênero elementos que indicam a objetivação comunicativa da cena, tais como a contextualização do ambiente onde se passa a história, lista de personagens e rubricas indicando ações. Esses elementos são comuns a textos de teatro, cinema ou televisão, por isso vamos usar o termo texto dramatúrgico, genericamente, mas vamos considerar o endereçamento como fator determinante na diferenciação dos formatos. 
O endereçamento, ou seja, o modo como o executor de um gênero busca se relacionar com seu público, também pode interferir nas escolhas estilísticas. Bakhtin (1997, p. 324) afirma que "o estilo depende do modo que o locutor percebe e compreende seu destinatário, e do modo como ele presume uma compreensão responsiva ativa”. Assim, partiremos do pressuposto de que a escolha do gênero textual está na gênese do processo criativo e as estratégias de endereçamento estão diretamente ligadas às intenções do autor em vista de seu público.

O texto dramatúrgico é uma espécie de gênero-valise, porque pode estar ligado, de forma fluida, a características de outros gêneros - tais como romance, biografia, contos, lendas e piadas - dando a eles forma de diálogos, monólogos ou apenas ações, tornando os limites entre um gênero e outro um tecido com tramas bastante permeáveis. O que caracteriza esse modelo textual é, basicamente, sua estrutura que é construída para possibilitar a encenação, com prospecções dos atos cênicos e propostas de combinações entre sons, palavras e imagens.

Faz-se necessário explicitar, portanto, que tomamos o conceito de gênero textual como uma estratégia de comunicação reconhecida socialmente pelas características que compõem sua forma. O texto dramatúrgico é direcionado para a ação e para a representação simbólica. Quando composto de diálogos ou monólogos, pressupõe a oralidade, afinal, deve permitir a transmutação simultânea da escrita para a fala e a ressignificação das palavras por meio da representação sonora e visual. Tradicionalmente, trazem rubricas de contextualização, lista de personagens e indicações para ações, figurinos, iluminação e cenário, sendo que o grau de detalhamento depende do estilo de cada roteirista/dramaturgo.

Assim como os suportes primários dos desenhos evoluíram, do pergaminho ao papel, passando por diferentes tipos de tecidos, os suportes do drama também evoluem, exigindo técnicas específicas. Enquanto gênero, o texto dramatúrgico pode ser desenvolvido em formatos diferentes, de acordo com o endereçamento. Neste caso, mantém-se o modelo de escrita que projeta a dramatização (estrutura narrativa dividida em atos e cenas, sequências dialogais, monólogos e rubricas), mas altera-se o tempo dramático, a organização das sequências e até o conteúdo das rubricas (ou didascálias), de acordo com o formato escolhido (minissérie, série, longa-metragem, novela, teatro etc.).

A distribuição dos elementos e a execução da linguagem irão depender do estilo individual do dramaturgo para animar as tensões propostas para narrativa e do estilo da própria obra. Em entrevista a nós concedida, Comparato afirmou que ao iniciar uma campanha de escrita já tem o gênero e o formato definidos, mentalmente: "Quando eu escrevo, eu já sei se a ideia serve para teatro, cinema, minissérie... enfim, eu jogo para onde eu acho que vai render e, claro, posso depois adaptar, como já fiz, transformando peça em filme, roteiro em romance e vice-versa" (2019).

A capacidade de antever a composição cênica - o jogo de luzes, a música, o gesto - está na gênese da criação dramatúrgica. A forma de pensar o gênero o caracteriza enquanto texto que evoca imagem, palavra e som. No entanto, nada garante a sintonia, ou a sinergia, entre o que imaginou o autor e o que será executado em cena. Temos aqui o conflito entre a intencionalidade, as estratégias para alcançar o objetivo e os efeitos gerados, sendo que estes últimos estão completamente fora de controle.

Concordamos com Almuth Grésillon (1995), para quem a gênese do texto de teatro dificilmente pode ser concebida sem levar em consideração as propriedades cênicas. No entanto, em que pesem possíveis interferências de diretores e atores no texto original, isso não interfere nas questões de autoria - exceto em casos de criação coletiva ou quando tais interferências são tão significativas que há um acordo de escrita a quatro ou mais mãos. Do contrário, estaríamos falando em uma espécie de ready-made, como o bigode na Mona Lisa de Duchamp, que revela o caráter mutável da arte, sem apagar a origem. 
Grésillon propõe a hipótese, com a qual também trabalhamos, de que a gênese do teatro, assim como o próprio texto dramatúrgico "está sempre ligada, de antemão, concreta e virtualmente, a configurações de encenação” (p. 270). Contudo, cada gênese é um caso particular e merece uma análise exclusiva. Encontramos na gênese criativa marcas autorais, que Pierrot (2005) chamaria de estilo de gênese, e um estilo singular da própria obra.

Embora não seja regra que a elaboração do texto anteceda o percurso da encenação - e há centenas de companhias teatrais trabalhando em sistemas coletivos ou colaborativos - o texto não está morto enquanto fora de cena, pelo contrário, vive além do contexto cênico. Neste artigo iremos abordar o fragmento de um texto dramatúrgico que não passou pelo crivo da cena, uma peça que foi publicada, embora seja inédita no palco. É o que convencionou-se chamar de closet drama, teatro escrito para ser lido, uma modalidade da qual se tem notícias desde a Roma antiga e da qual Alfred Musset foi um grande adepto.

O closet drama propõe uma abertura ou incompletude, que só pode ser preenchida pela imaginação do leitor em relação a passagem da palavra à imagem. É justamente essa característica de obra aberta, até certo ponto prescritiva, que mantém a palavra escrita sempre viva em algum espaço entre o suporte que a abriga e as possibilidades de realização.

\section{Comparato e a Escrita Dramatúrgica}

No estilo de criação textual de Doc Comparato, o trabalho se desenvolve em etapas e com uma disciplina específica. Um período de entrega à pesquisa antecede a organização da escrita quando há delimitação de um tema. Há um aprofundamento nos estudos históricos e bibliográficos para criação do enredo e das personagens, e também uma busca por referências visuais no cinema, na televisão e nas artes plásticas.

Soma-se à pesquisa uma coleção de memórias que se recicla e se recombina em diferentes trabalhos. Muitos pensamentos e achados (imagens marcantes, palavras, histórias contatas por terceiros, frases de que gosta) são registrados para uso oportuno. O cotidiano, o convívio com outras pessoas, e o que essas relações despertam em termos de prazer ou novidade, juntam-se ao diálogo filosófico interno que desencadeia o processo.

Tudo o que marca a memória sensível é, aos poucos, trazido para o concreto em forma de notas, manuscritas em pedaços de papel, cadernos, guardanapos e blocos adesivos. Essa coletânea de informações vai se decantando com o passar do tempo, nem sempre com prazo definido para tomar parte em um trabalho. Quando um enredo se configura no plano mental, Comparato começa a campanha de escrita, alinhavando ideias, harmonizando o que parece difuso e transformando em linguagem. Ele também gosta de ouvir músicas enquanto escreve, como se a sonoridade ajudasse a conduzir a pulsação da palavra ou induzisse a uma determinada atmosfera de criação.

O roteiro é definido por Comparato como "a forma escrita de qualquer forma audiovisual” e, quando se põe a prepará-lo, define logo o endereçamento. A estruturação da ação dramática segue uma lógica préestabelecida, uma organização já prevista na sinopse. Ao sentir que tem a história pronta e um argumento bem amarrado, o dramaturgo gosta de começar a escrita pelo título e seguir uma ordenação formal, rascunhando o prólogo, a lista de personagens e a sequência de cenas. Há uma preferência nítida pelo discurso interativo relatado com cenas em sequências dialógicas entremeadas por rubricas:

Tenho uma tendência a não usar off. É um recurso que algumas vezes é necessário para solucionar a cena. Mas é um recurso que evito para não infantilizar o texto, torná-lo muito explicativo. Não posso dizer que dessa água não bebi ou não beberei, mas não gosto de off que diz o que precisa ser mostrado com ações. (COMPARATO, 2019). 
Há outras tendências estéticas que se repetem com frequência na escrita de Comparato. No primeiro texto escrito para teatro, em 1978, o dramaturgo elegeu o três (3) como uma espécie de número da perfeição. Plêiades é uma compilação de três peças escritas para três atrizes (e um ator), que faz parte da Trilogia do Amanhã. Essa primeira peça tem apenas um título e um subtítulo (Pequena trilogia para aracnídeos). Essa busca pelo formato preferido de Ésquilo, o pai da tragédia, é retomado nas trilogias do Tempo e da Imaginação, sendo que nesta última também adotou três títulos para cada texto e os dividiu em três atos. A educação católica e o mistério da Santíssima Trindade também podem ter influência sobre essa escolha. Coincidentemente, Comparato nasceu no dia 3 de novembro e teve três filhas.

Mas essa preferência nunca foi uma fixação ou prisão, é apenas parte de uma série de escolhas em determinados momentos da carreira. O dramaturgo afirma que a matriz do próprio estilo é a fragmentação estrutural. De fato, este elemento está presente em alguns de seus textos e parece ser uma clara influência do teatro, da literatura, das artes plásticas e do cinema modernistas, que marcaram fortemente a formação estética de Comparato e, consequentemente, sua memória. A fragmentação é mais intensa nos textos para teatro, tais como O beijo da louca, de 1978, ou Sempre, de 2003. Mas essa característica parece-nos uma busca consciente por efeitos expressivos em algumas narrativas.

Analisando manuscritos, ouvindo o roteirista e acompanhando o trabalho de Comparato, percebemos uma necessidade de domínio sobre o fluxo da memória afetiva e da imaginação, um impulso para reter momentos e sensações no espaço e no tempo por meio de palavras. É a êxtase diante do belo e a curiosidade pelo mistério que o impulsionam a construir formas, harmonizando em linguagem simples experiências íntimas e referências eruditas. O escritor explora várias formas de intertexto, explícitas e implícitas.

As rasuras, acréscimos, substituições e deslocamentos encontrados nos rascunhos revelam um esforço para tornar os diálogos simples, diretos e dinâmicos como a própria fala. Mesmo nos monólogos interiores, Comparato introduz quebras e digressões que os assemelhem à língua falada. É durante esse afinamento que se dão as revisões e tratamentos no texto. De acordo com o dramaturgo, a grande diferença entre o primeiro tratamento e o texto final é a lapidação da escrita "é a transformação do primeiro roteiro, um texto, numa ferramenta de trabalho que será entregue a uma equipe para ser traduzida em imagens e som" (COMPARATO, 2018, p. 264).

\section{Eterno e a Trilogia da Imaginação}

A Trilogia da Imaginação aborda, de forma global, o ofício do criador e os conflitos gerados pela necessidade de construir algo capaz de expressar desejos íntimos, sonhos... enfim, a imaginação. Em Sempre, a protagonista é uma escritora ficcional, Adélia. Em Eterno, a narrativa gira em torno do cineasta norte-americano, Orson Welles. Em Jamais, o papel do "criador" não recai sobre o protagonista, Calabar, mas sobre a personagem do príncipe Maurício de Nassau, que planejava erguer, no nordeste brasileiro, a Cidade Maurícia. A escritora que luta pela carreira, o cineasta que chega ao topo e perde tudo, o arquiteto narcisista, que não consegue concluir a cidade dos sonhos. A trilogia parece representar o dragão de três cabeças que o próprio autor quer derrotar.

A cronologia das peças é questionável, uma vez que há rasuras nos manuscritos e a data da publicação oficial é muito posterior. No entanto, comparando manuscritos e informações coletadas nas entrevistas, concluímos que Sempre foi a primeira da sequência, com uma fragmentação muito maior e um processo de escritura que reflete, de certo modo, o caos emocional, estilístico e criativo atravessado pelo escritor naquele momento específico, que leva a uma experimentação maior, inclusive com a sobreposição de flashbacks e o avanço na fragmentação como uma reafirmação de estilo. 
Jamais começou a ser escrita em fevereiro de 2006, em Barcelona, e é o texto mais fluido da trilogia, mais conectado com o sistema de escrita para audiovisuais proposto por Comparato. O ritmo dos diálogos é mais orgânico e a construção da narrativa resgata muito da essência do dramaturgo e seu histórico de escrita para televisão, com a criação de imagens impactantes, tensões e suspenses, uma característica que se relaciona com a gênese da obra. Embora o texto teatral seja relativamente recente, o argumento remonta ao fim dos anos de 1980.

Entre julho e agosto de 2006, de volta ao Rio de Janeiro, escreve a última parte da trilogia, Eterno, em que resgata a fixação pelo mistério, pelas previsões apocalípticas e insere o contexto da guerra, como uma metáfora da destruição, do fim, das situações limite e dos recomeços no deserto da imaginação. Embora a história ficcional esteja situada no nordeste brasileiro, o retorno de Comparato ao Rio influencia os contornos da peça, uma vez que Orson Welles esteve ali na década de 1940 para filmar o carnaval carioca, frequentou casas noturnas na Urca e deixou suas marcas na cidade.

Tanto a Trilogia do Tempo quanto a Trilogia da Imaginação foram publicadas apenas em 2013, juntamente com a reunião de seus primeiros textos teatrais, a Trilogia do Amanhã. $\mathrm{O}$ autor decidiu publicar apenas os textos para teatro, por considerar que os roteiros para cinema ou televisão já foram transformados em produtos audiovisuais, tornaram-se "outra coisa", nas palavras dele: "a crisálida já virou borboleta". Comparato considera que os textos para teatro são portadores da "palavra viva", a palavra que é ressignificada cada vez que é pronunciada.

Cada uma das peças traz três títulos, sendo que o primeiro tem caráter abstrato, que remete à grande questão filosófica do texto; o segundo é concreto, remete ao tema e ao texto em si; o terceiro cria uma ligação entre as três partes, posicionando cronologicamente e contextualizando a trilogia em princípio, meio e fim, a lógica da narrativa. Entretanto, o terceiro título também nos revela a grande metáfora do ofício do criador: a entrada nesse universo, a conquista da identidade e a percepção de que nem tudo está sob controle.

Quadro 1 - Os títulos triplos da Trilogia da Imaginaşão

\begin{tabular}{|l|l|l|}
\hline 1.o título & 2.o título & 3.o título \\
\hline Sempre & O caso da garota de gargantilha & Na intimidade das coisas \\
\hline Jamais & Calabar, um elogio à traição & Na posse das coisas \\
\hline Eterno & Xanadu, no limite da criatividade & No inalcançável das coisas \\
\hline
\end{tabular}

Fonte: Elaborado pelas autoras.

O primeiro título de cada peça trata do inexplicável, do mistério, da capacidade que a palavra tem de conter e significar uma abstração que pode ser compreendida, mas não pode ser comprovada. Palavras cuja concretude só pode ser tocada pela arte, carregando a ideia da temporalidade. Os segundos títulos correspondem ao desenvolvimento da história, são palpáveis, visíveis, alcançáveis. Falam sobre o tema ou sobre a grande metáfora que norteará a narrativa. Os terceiros títulos fecham um ciclo (a tríade), ligam o material (as coisas) ao abstrato: a eternidade inalcançável, as coisas jamais possuídas e a presença imaterial evocada pelas coisas.

\section{Os Dias Secretos de Orson Welles no Brasil}

Eterno, a terceira parte da trilogia, é uma rendição à efemeridade da vida e de tudo o que é criado pelo homem. A peça tem como mote os dias em que Orson Welles deixou de entrar em contato com a própria 
equipe de filmagem, no Brasil, quando tudo parecia dar errado nos trabalhos do cineasta norte-americano. A grande razão daquela empreitada em terras tropicais, nos idos de 1942, era filmar o carnaval e outras histórias pitorescas que corroborassem os interesses políticos comuns entre América Latina e Estados Unidos.

Uma série de reflexões, anotadas por Comparato em folhas adesivas de pequenos blocos de notas, alimentam a construção filosófica do texto, como células que se expandem, multiplicam ou aglutinam, compondo novas estruturas. São frases como: "Nem o cinema é eterno, porque é feito de sombras e luz"; "Nem a luz é eterna, só a sombra"; "O eterno é o nada. A sombra. Nada é eterno"; "A resignação é o sentimento de que nada vale a pena"; "Chega no céu ou no eterno uma carta de reclamação"; "Escorpião? Monte Sinai"; ou "Não sei ser artista / todos consideram um talento e fazer das coisas arte é a mitologia dos despossuídos”.

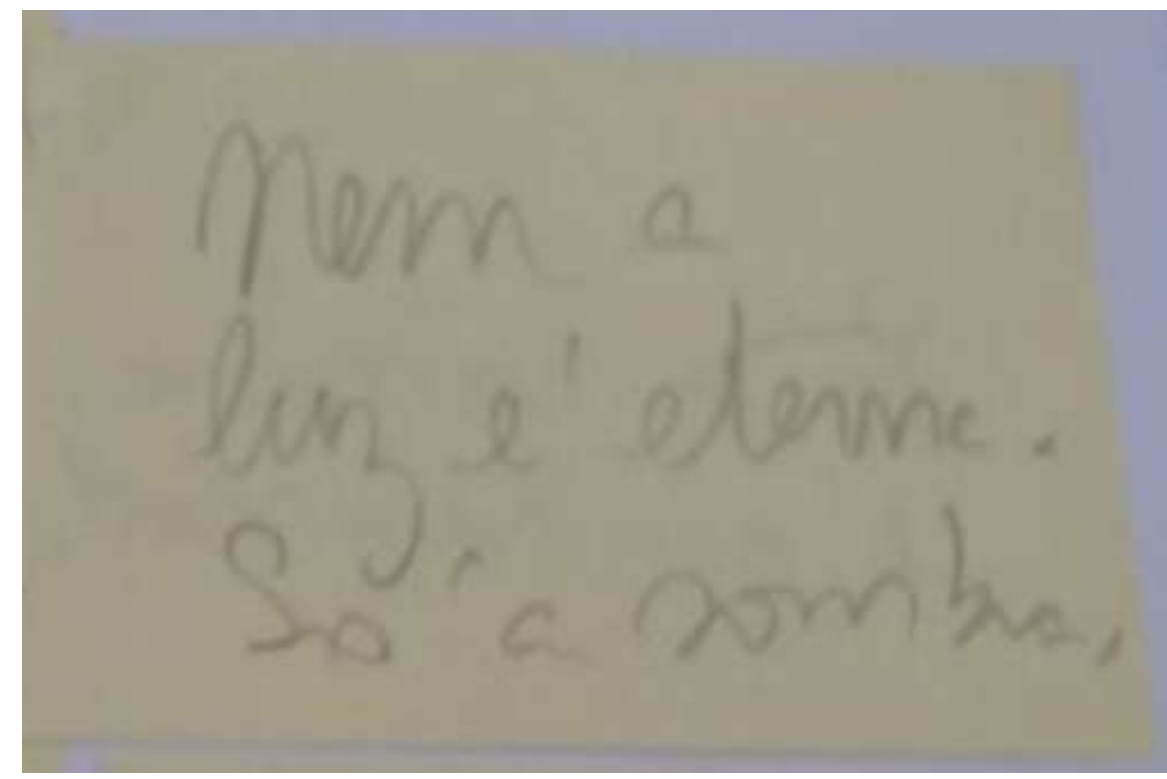

Fonte: Doc Comparato, acervo pessoal.

Imagem 1 - Nota em folha adesiva

Esses pensamentos, registrados e guardados, indicam o movimento de retenção das ideias, para que possam ser retomadas e desenvolvidas. Algumas tomarão forma de diálogo, tal como na cena treze, a Cena da jangada:

(O.W.) - Por favor, não jogue a filmadora no mar. Vai destruir imagens maravilhosas.

(Madalena) - Mas não era eterno?

(O.W.) - Foi um modo de dizer.

(Madalena) - Não sou burra, nem tola. Entendi perfeitamente: foi um modo de dizer que a palavra 'eterno' sempre precisa de 'Xanadus' para existir.

Nesta terceira peça, Comparato quer ir ao limite, fazendo convergir mitologia grega, arquétipos judaico-cristãos, cultura popular brasileira e a influência norte-americana no pós-guerra em um texto que evoca o realismo fantástico - referência a Gabriel García Márquez, com quem o dramaturgo trabalhou e manteve uma longa amizade. Assim como em Cem anos de solidão, o roteiro de Comparato se passa em um vilarejo ficcional e envolve uma família confrontada com seu destino, traçado a partir de uma origem de pecado, que carece de redenção. 
O elo entre a realidade e a magia não é, como se pode imaginar inicialmente, a bagagem de Orson Welles, cheia de truques cinematográficos. Quando o cineasta chega a um território perdido no litoral cearense, descobre histórias que estavam além dos efeitos especiais. Ele conhece o jovem Bento, que tem intimidades com a terra e se comunica com o céu, fazendo previsões incompreensíveis.

Uma das profecias diz que irá "nevar sobre o mar do Ceará e em cima do areal”. Há nesta fala da personagem uma referência à figura do líder do Arraial de Canudos, Antônio Conselheiro, que profetizou, nos fins do século XIX: “o sertão vai virar mar e o mar vai virar sertão”. Comparato resgata, nas profecias de Bento, as crendices do sertão brasileiro; a essência da tragédia clássica (o confronto do homem com seu próprio destino); e as nuances apocalípticas da guerra, que destrói mundos conceituais para construção de outros.

Fatos verídicos não entram no texto de Comparato, que faz justamente o contrário: aproveita a brecha oculta da história para criar uma aventura totalmente ficcional vivida por Welles nos dias misteriosos em que o cineasta tomou um jipe e sumiu pelo litoral, sem dar explicações. Analisaremos a primeira cena de Eterno, a abertura do texto teatral, onde se estabelece a atmosfera da narrativa, a representação do encontro entre a realidade e a criação artística, a cena do ovo selvagem.

No texto teatral, primeiro se estabelece o território da fantasia e, aos poucos, estimula-se a imaginação dos leitores/espectadores para que embarquem naquele mesmo tempo e lugar ficcionais, delimitados pela imagem e energia que se pretende criar para o espaço único do palco. Os recursos linguísticos usados para seduzir o público são modificados quando Comparato endereça a narrativa para o cinema. O formato proposto para a tela torna possível um número maior de cenas, ambientes e personagens. E também pede uma adaptação nas representações simbólicas.

O ritmo é diferente, pois a cena não é vista diretamente pelo olho humano, mas traduzida pelo "olho" da câmera e filtrada pelos cortes de edição. No teatro, o tempo e a delimitação de espaço da realidade são compartilhados com o público e são simultâneos ao tempo/espaço da ficção. As telas, de modo geral, quebram essa relação, de modo que o público pode comungar do tempo da ficção sem que ele seja simultâneo ao tempo real e sem partilhar o espaço da encenação. Essa quebra propicia o reestabelecimento dos limites entre as formas de realização do drama e um novo campo de exploração da linguagem.

A adaptação feita por Comparato, de um formato para o outro, começou pelo título: em vez de Eterno, a versão para cinema foi intitulada Os dias secretos de Orson Welles no Brasil, desvinculando o texto da Trilogia da Imaginação. A palavra "Eterno" também foi suprimida ou substituída nos diálogos do roteiro cinematográfico. O formato do texto para filme incluiu três participações especiais (o Capitão do exército, o Mordomo e o Babalorixá), além de um número indefinido de figurantes como bailarinas e frequentadores do cassino.

Em vez de privilegiar o ingresso direto no espaço do realismo fantástico, ou seja, no vilarejo ficcional - como faz na primeira cena de Eterno - Comparato prioriza, na abertura do roteiro cinematográfico, a caracterização de Orson Welles e os elementos históricos da estada dele no Brasil, baseados em relatos: as festas, a bebedeira e a lascividade. Apenas na oitava cena, Comparato começa a trançar o texto teatral com o novo formato, embora a gênese de ambos seja a mesma.

No Quadro 2, na página seguinte, vamos compor o movimento de transição entre o primeiro rascunho do texto teatral, suas transformações até a versão publicada em 2013, e o primeiro digitoscrito para cinema, preparado em 2018. Tomamos como amostra a primeira cena do texto teatral (cena do ovo selvagem), que será deslocada para oitava cena do roteiro cinematográfico e dividida em quatro outros cortes. Marcamos com grifos e negrito elementos que sofreram alterações, demonstrando a variação textual ao longo do processo. 


\begin{tabular}{|c|c|}
\hline Original & $\begin{array}{l}\text { Luz ganha intensidade. Amanhece. Madalena jovem como uma moça brejeira vestindo um encorpado vestido } \\
\text { de chita, lava molha e lava três ovos grandes de uma ave alguma ave selvagem. Ela está acocorada de cócoras. } \\
\text { Instantes. Da penumbra nasce a luz que ilumina delineia um cavalete de pintor espetado numa das três dunas } \\
\text { de areia. Ela segue distraída limpando os ovos. A presença do cavalete vai tomando corpo até reinar por sobre a } \\
\text { paisagem. Por fim ela se vira e enxerga o cavalete de costas para que ñ sem que se veja a pintura ou se esta Os } \\
\text { ovos são largados. Madalena perde a respiração. Fica estarrecida vai se aproximando do cavalete como se fosse } \\
\text { um totem. Instantes. Poço de êxtase e surpreendência, o dedo de Madalena toca por fim toca o cavalete como } \\
\text { se fosse um objeto sagrado. E cheia de energia grita enquanto chama. } \\
\text { Madalena: Pai. Pai... Pai! Pai! Pai! } \\
\text { Instantes. Tudo escuro. }\end{array}$ \\
\hline $\begin{array}{l}1 . \\
\text { o tratamento }\end{array}$ & $\begin{array}{l}\text { Luz ganha intensidade. Amanhece. Madalena, tal moça brejeira, vestindo um encorpado vestido de chita, molha } \\
\text { e lava três ovos grandes de uma ave selvagem. Ela está de cócoras. Instantes. Da penumbra nasce a luz que } \\
\text { delineia um cavalete de pintor, espetado no topo de uma das três dunas de areia. Ela segue distraída limpando os } \\
\text { ovos, enquanto a presença do cavalete vai tomando corpo até reinar sobre a paisagem. Por fim ela se vira e } \\
\text { enxerga o cavalete suspendendo a tela sem que se veja a pintura. Os ovos são largados. Madalena perde a } \\
\text { respiração. Fica estarrecida vai se aproximando do cavalete como se fosse um totem. Instantes. Poço de êxtase e } \\
\text { surpreendência, o dedo de Madalena por fim toca o cavalete como se fosse um objeto sagrado. E cheia de } \\
\text { energia grita enquanto chama. } \\
\text { Madalena: Pai. Pai... Pai! Pai! Pai! } \\
\text { Instantes. Tudo escuro. }\end{array}$ \\
\hline $\begin{array}{l}2 . \\
\text { o tratamento }\end{array}$ & $\begin{array}{l}\text { Luz ganha intensidade. Amanhece. Madalena, tal moça brejeira, vestindo um encorpado vestido de chita, molha } \\
\text { e lava três ovos grandes de uma ave selvagem. Ela está de cócoras. A água brilha e reflete. Instantes. Da } \\
\text { penumbra nasce a luz que delineia um cavalete de pintor, espetado no topo de uma das dunas de areia. } \\
\text { Ela segue distraída limpando os ovos, enquanto a presença do cavalete vai tomando corpo até reinar sobre a } \\
\text { paisagem cenográfica. Por fim ela se vira e enxerga o cavalete suspendendo uma tela sem que se veja a pintura. } \\
\text { Os ovos são largados. Madalena perde a respiração. Fica estarrecida vai se aproximando do cavalete como se } \\
\text { fosse um totem, algo divino, um ídolo. Instantes. Medo e Existe medo e admiração. Poço de êxtase e } \\
\text { surpreendência, o dedo de Madalena por fim toca o cavalete com cerimônia como se fosse um objeto sagrado } \\
\text { um ídolo. A encenação deve ser plasticamente explêndida. E cheia de energia grita enquanto chama. } \\
\text { Madalena: Pai. Pai... Pai! Pai! Pai! } \\
\text { Instantes. Tudo escuro. }\end{array}$ \\
\hline $\begin{array}{l}3 . \\
\text { o tratamento }\end{array}$ & $\begin{array}{l}\text { Luz ganha intensidade. Amanhece. Madalena, tal moça brejeira, vestindo um encorpado vestido de chita, molha } \\
\text { e lava três ovos grandes de uma ave selvagem. Ela está de cócoras. A água brilha e reflete, parece espelhada. } \\
\text { Instantes. Da bruma e da penumbra nasce a luz que delineia um cavalete de pintor, espetado no topo de uma } \\
\text { das dunas de areia. Ela segue distraída limpando os ovos, enquanto a presença do cavalete vai tomando corpo } \\
\text { até reinar sobre a paisagem cenográfica. Por fim ela se vira e enxerga o cavalete suspendendo uma tela sem que } \\
\text { se veja a pintura. Os ovos são largados. Madalena perde a respiração. Fica estarrecida vai se aproximando do } \\
\text { cavalete como se fosse um totem, algo divino. Instantes. Existe medo e admiração. Poço de êxtase e } \\
\text { surpreendência, o dedo de Madalena por fim toca o cavalete com cerimônia como se fosse um objeto sagrado } \\
\text { um ídolo. A encenação deve ser plasticamente explêndida. E cheia de energia grita enquanto chama. } \\
\text { Madalena: Pai. Pai... Pai! Pai! Pai! } \\
\text { Instantes. Tudo escuro. }\end{array}$ \\
\hline $\begin{array}{l}\text { Versão final } \\
\text { teatro }\end{array}$ & $\begin{array}{l}\text { (Luz ganha intensidade.) } \\
\text { (Amanhece.) } \\
\text { (Madalena, tal moça brejeira, vestindo um encorpado vestido de chita, molha e lava três ovos grandes de uma } \\
\text { ave selvagem. Ela está de cócoras.) } \\
\text { (A água brilha e reflete. Parece espelhada.) } \\
\text { (Instantes.) } \\
\text { (Da bruma e da penumbra nasce a luz que delineia um cavalete de pintor, espetado em uma das dunas de areia.) } \\
\text { (Ela segue distraída limpando os ovos, enquanto a presença do cavalete vai tomando corpo até reinar sobre a } \\
\text { paisagem cenográfica.) } \\
\text { (Enfim ela se vira e enxerga o cavalete suspendendo uma tela sem que se veja a pintura.) } \\
\text { (Os ovos são largados.) } \\
\text { (Madalena perde a respiração. Fica estarrecida, vai se aproximando do cavalete como se fosse um totem, algo } \\
\text { divino.) } \\
\text { (Instantes.) } \\
\text { (Existe medo e admiração.) } \\
\text { (Poço de êxtase e surpreendência, o dedo de Madalena por fim toca com cerimônia o cavalete como se fosse um } \\
\text { objeto sagrado. Um ídolo.) } \\
\text { (A encenação deve ser plasticamente esplêndida.) } \\
\text { (Cheia de energia grita enquanto chama.) } \\
\text { MADALENA: Pai. Pai... Pai! Pai! } \\
\text { (Instantes.) } \\
\text { (Tudo escuro.) }\end{array}$ \\
\hline
\end{tabular}




\begin{tabular}{|c|c|}
\hline $\begin{array}{l}1 . \\
\text { a versão do } \\
\text { digitoscrito } \\
\text { para cinema }\end{array}$ & $\begin{array}{l}\text { Imagem abre-se no azul intenso. Amanheceu. A lagoa é azul, água cristalina. Reflexo dela na água. Vemos } \\
\text { Madalena de cócoras. Trata-se de uma moça brejeira, usando um encorpado vestido de chita. Ela lava, corta, } \\
\text { destripa e descama alguns peixes. Ao seu lado tem uma bacia de barro avermelhado intenso, onde ela coloca } \\
\text { os peixes limpos. Do outro lado vemos um puçá, de rede negra, com os peixes que ela deve ter pescado. O } \\
\text { brilho de sua faca é intenso frente ao sol. Segue música. Instantes. } \\
\text { CORTE PARA (cena 09): } \\
\text { Agora, Madalena caminha pelo cajueiro (considerado um dos maiores do mundo). Ele está recheado de cajus } \\
\text { amarelos e vermelhos. Detalhar. Os troncos negros lembram enormes trombas e animais pré historicos em } \\
\text { forma de grandiosas serpentes. Entre sombras e feixes de raios solares, troncos, folhas e frutos, ela anda } \\
\text { segurando a bacia de barro e o puça vazio. } \\
\text { (Apontamento musical). } \\
\text { (Instantes). } \\
\text { CORTE PARA (cena 10): } \\
\text { EXT. DUNA DO CAVALETE / NORDESTE / DIA10 Imagem abre-se no branco imaculado, da areia das } \\
\text { dunas. Agora Madalena caminha descalça sobre a areia. Lê-se a legenda: Dunas - Nordeste do Brasil - } \\
\text { 1942. Subitamente ela para. Intrigada, ela se aproxima do topo da duna onde reina um cavalete com um quadro } \\
\text { (devido ao reflexo da luz do sol, lembra por um instante uma cruz). Ela larga a bacia de peixe na areia, } \\
\text { enquanto circunda o cavalete e a pintura. Estranhando a presença do objeto num local tão deserto. Não se vê } \\
\text { o que está pintado no quadro. É bem provável que a tela esteja em branco. Com êxtase e surpreendência, o } \\
\text { dedo de Madalena por fim toca com cerimônia a tela como se fosse um objeto sagrado. Um ídolo. Ela fica } \\
\text { pensativa. Inesperadamente, Madalena sai correndo deixando sua bacia de peixe para trás. } \\
\text { CORTE PARA (cena 11): } \\
\text { EXT. CASA MIGUEL / PROXIMO AO MAR / NORDESTE / DIA11 Vemos uma parede branca de um } \\
\text { casebre com uma janela fechada de madeira azul. Pode ter um flamboyant em flor vermelha descendo numa } \\
\text { parte do telhado abaixo. Madalena ofegante bate com força na janela azul escuro. MADALENA Pai! Pai! Pai! } \\
\text { Instantes. }\end{array}$ \\
\hline
\end{tabular}

Fonte: Elaborado pelas autoras.

No rascunho original temos o primeiro jato de escrita, em que o dramaturgo põe as palavras no papel em fluxo contínuo, com pequenas hesitações seguidas de alternativas para posterior escolha. Assim, ele emenda "uma ave alguma ave", "acocorada de cócoras" ou "ilumina delineia". Na primeira releitura do próprio texto, que corresponde ao primeiro tratamento, percebemos a opção por "uma ave"; "de cócoras" e "delineia". São mudanças sutis, mas que aperfeiçoam a expressividade. Embora a "ave" siga indeterminada, regida por um artigo indefinido, já não é mais "alguma ave", que poderia implicar um efeito depreciativo de uma ave qualquer. Assim como "iluminar" é uma palavra que evoca, semanticamente, uma luz forte, vertical, mais intensa do que apenas "delinear", que remete a uma luz suave, horizontal.

No primeiro tratamento destacamos as lexias e expressões que compuseram o ajuste durante a primeira fase da construção textual. Frases mal finalizadas no primeiro rascunho são refeitas, conforme vemos em "o cavalete suspendendo a tela sem que se veja a pintura". No segundo tratamento observamos diversos acréscimos, como uma busca por definir melhor o efeito cênico desejado, a ação como texto silencioso da personagem.

Percebemos a tensão para encontrar palavras cujo significado componha conceitos que possam ser transformados em imagens concretas. Conforme Monteiro (1991, p. 104), "o significado de uma unidade linguística abrange a imagem mental (o conceito), as repercussões afetivas, a imaginação sensorial, bem como os valores sociais". No caso do texto dramatúrgico, há representações de conceitos passíveis de serem reconstruídos na encenação.

Temos tanto a indicação precisa do que se espera do efeito cenográfico na frase "a água brilha e reflete" até o detalhamento das sensações que Madalena deve expressar ao se deparar com o cavalete, pois deve exteriorizar mais que do que admiração ou êxtase. Para que isso se concretize, o autor se vale da palavra entrecruzada "surpreendência", um portmanteau criado para fazer transparecer o comportamento que se esperava da personagem diante de algo "divino", através da soma das sensações de "surpresa" e "prudência". Guilbert (1975) afirma que a criação de neologismos está ligada à originalidade do indivíduo e à sua liberdade para dizer coisas de forma personalizada. 
No terceiro tratamento estão dois acréscimos, evidentes no manuscrito pelo uso de uma caneta de tinta preta, possivelmente feitos durante a revisão do texto que foi enviado para a editora, em 2013. Esse mesmo tom de tinta, mais escuro, também aparece em revisões finais de outros manuscritos da Trilogia da Imaginação, o que nos leva a concluir que tenham sido feitas anos depois das primeiras revisões, quando o autor decidiu publicar o compilado. Apesar do tempo entre uma releitura e outra, pouco foi alterado na cena de abertura.

O excerto destacado no quadro é praticamente todo composto por rubricas (ou didascálias) que, no texto dramatúrgico, correspondem à orientação para a ação. Embora não seja o texto escrito para ser falado pelos atores, percebemos o cuidado do dramaturgo na escolha das palavras e a delicadeza para estabelecer o ambiente, o clima que se espera durante a encenação, não apenas no detalhamento dos efeitos visuais da cenografia e na expressividade não verbal da personagem, mas também na atenção com cacófatos (acocorada/ de cócoras) e duplos sentidos (como moça/tal moça).

$\mathrm{Na}$ versão final pede-se que a cena seja "plasticamente esplêndida", algo bastante subjetivo, daí uma seleção lexical tão específica para definir o tom da iluminação (bruma, penumbra, delineia) e também para dar ao contato entre Madalena e o cavalete o toque divinal da criação, semelhante à pintura de Michelangelo no teto da Capela Sistina, afinal, não é a mão de Madalena que pega com cerimônia o cavalete, é o dedo que o toca "como se fosse um objeto sagrado". Todo silêncio, harmonia e esplendor da cena são quebrados depois desse gesto, em que a mulher toca o espaço desconhecido da tela em branco. Ela chama pelo pai, e a rubrica pede que esse chamado seja um grito, empregado com energia. É a única fala que encerra a cena de abertura.

Há que se ressaltar que a publicação de Eterno, escrito de maneira independente, não estava vinculada a um diretor, encenador ou companhia teatral, ou seja, sua existência enquanto espetáculo não estava prevista de maneira concreta, o que pode ter contribuído para que as didascálias tenham assumido nuances poéticas e certo grau de detalhamento. Nem sempre todas as intenções ficam registradas quando a equipe participa do processo e contribui para as soluções cênicas.

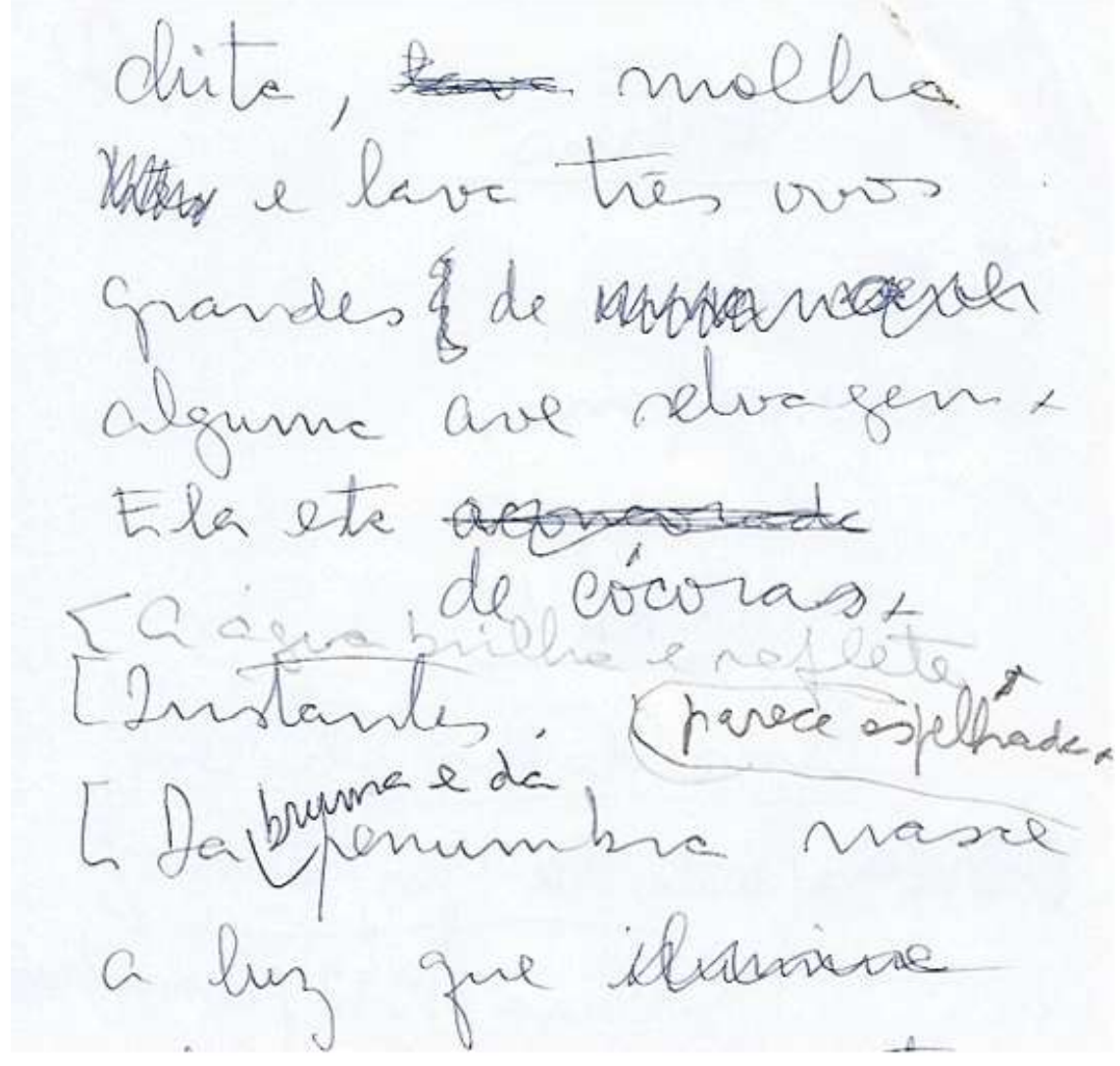

Fonte: Doc Comparato, acervo pessoal.

Imagem 2 - Rascunho Cena do ovo selvagem 
No roteiro para cinema, a Cena do ovo selvagem é fragmentada em quatro partes, ou cortes, e já não tem mais esse nome, pois os ovos, objetos simbólicos que condensam o mistério da gênese, podem ser substituídos por outros elementos, em locações ampliadas. O pacto proposto para uma plateia de teatro - que é convidada a participar de um jogo de representações - dá lugar a uma concepção mais realista da aldeia de pescadores, algo captável pela gravação. As rubricas trazem indicações sobre o que a câmera deve mostrar: "a imagem abre-se no azul”, "vemos Madalena", "vemos um puçáa, "vemos a parede".

Comparato também propõe que sejam exploradas imagens da natureza local, como as cores e formas do cajueiro e a lagoa. Há também a indicação de uma legenda, trazendo localização geográfica e data. São possibilidades de metamorfoses textuais abertas pela mudança de endereçamento do texto. Não avançaremos sobre o desenvolvimento da criação cinematográfica, pois isso implicaria adentrarmos em outro processo, sob influência de outra linguagem.

As rubricas do roteiro fílmico trazem uma adjetivação intensa e altamente metafórica. Muitas prospecções imagéticas remetem ao paraíso bíblico, uma outra forma de representação da gênese. A água é "cristalina", a areia das dunas por onde Madalena caminha "descalça” é de um branco "imaculado". As raízes do cajueiro devem parecer "animais pré-históricos" ou "grandiosas serpentes" e pede-se o detalhamento, ou seja, o destaque para os frutos da árvore, uma relação implícita entre árvore/vida-fruto/mistério-serpente/ desejo.

O roteirista indica a predominância da tríade de cores primárias, ou puras, nos objetos cenográficos (azul, amarelo e vermelho), além do preto e do branco, remetendo ao tudo e ao nada. A luz, que torna tudo visível, inclusive a sombra, também é representada pelo brilho dos objetos. Percebemos, ainda, uma preocupação com a representação dos elementos da natureza: água (peixes), ar (céu), fogo (sol) e terra (dunas) que no texto teatral eram, respectivamente, água, bruma, luz intensa e areia.

\section{Considerações Finais}

Nos documentos de processo de Eterno pudemos observar várias fases do movimento criador de Doc Comparato. Da fase pré-redacional resgatamos notas avulsas que funcionam como células germinativas no processo de escrita, e que remanescem como traços memoriais da criação textual. Algumas dessas anotações revelam questões filosóficas importantes que embasam o enredo de Eterno, levantando questões sobre a perenidade das coisas. Naquelas frases, Comparato expressa a certeza de que nada permanece, nem mesmo a luz, apenas as sombras. E essa definição é a linha condutora da narrativa.

$\mathrm{Na}$ fase redacional, exploramos os rascunhos da primeira cena, composta basicamente por rubricas que estabelecem a atmosfera desejada para o espetáculo. Ainda que não seja um texto a ser falado pelos atores, percebemos um cuidado com a escolha das palavras e uma preocupação em expressar o que se deseja da ação dramática. O fato de ser um texto publicado para leitura, antes de sua possível encenação, também contribui para o detalhamento das didascálias.

Os documentos de processo de Eterno nos permitiram ainda compreender as variações textuais provocadas pela mudança de endereçamento que transformaram a peça para teatro em um roteiro para cinema. As ações deixam de ser endereçadas ao olho humano e passam a ser prospectadas para a captação da câmera e para a edição.

Embora a fala da personagem não tenha sofrido alterações, as didascálias tomaram contornos completamente diferentes e as representações simbólicas também. A primeira cena do texto teatral desdobra-se em quatro cortes no roteiro cinematográfico. Houve troca de cenários, adereços e de recursos técnicos, tais como iluminação, trilha sonora etc, para possibilitar a aplicação metafórica da "origem" a outro formato dramatúrgico. 
A partir dessa metamorfose, o texto final para teatro ganha mobilidade novamente, e passa a integrar o processo de criação do roteiro cinematográfico. A primeira versão digitoscrita do roteiro para cinema, por sua vez, é ainda uma etapa em aberto, uma variável de outro mecanismo criativo em fase inicial que, possivelmente, receberá interferências dos artistas que o executarão.

Embora a prospecção para a cena faça parte da gênese, a mudança de endereçamento em relação ao agente passivo no ato de linguagem provoca deslocamentos no fazer da escrita, de acordo com a concepção de Doc Comparato sobre os diferentes formatos. No excerto escolhido para este artigo, pudemos observar a maneira com que o dramaturgo compreende e executa a variação textual, considerando o destinatário. $\mathrm{O}$ roteiro, ou guião, não conduz mais a encenação diretamente para os olhos da plateia, mas considera a mediação da câmera e o processo de edição.

Chegamos a um estilo de gênese metódico, que busca o domínio da forma por meio da escolha de palavras evocatórias, com denso potencial imagético. A coleção de notas pré-redacionais, as etapas que precedem a campanha de escrita, os movimentos de prospecção e retrospecção, as releituras e reformulações podem ser comparados às gêneses de outras obras do dramaturgo de modo que possamos identificar as repetições que compõem a marca do autor e as singularidades de cada texto.

\section{REFERÊNCIAS}

ALONSO, A. Materia y forma en poésia. 3. ed. Madrid: Gredos, 1969.

BAKHTIN, M. Estética da criação verbal. Tradução Maria Ermantina Galvão G. Pereira. São Paulo: Martins Fontes, 1997.

COMPARATO, D. Eterno. Rio de Janeiro: Simplíssimo Livros, 2013. Edição digital.

COMPARATO, D. Jamais. Rio de Janeiro: Simplíssimo Livros, 2013. Edição digital.

COMPARATO, D. Sempre. Rio de Janeiro: Simplíssimo Livros, 2013. Edição digital.

COMPARATO, D. Da criação ao roteiro. 11. ed. São Paulo: Summus, 2018.

COMPARATO, D. Conversa. [Entrevista concedida a] Edina Regina Pugas Panichi e Livia Sprizão de Oliveira. Cascais, Portugal, 28 nov. 2019.

FERRER, D. La toque de Clementis: rétroaction et rémanence dans les processus génétiques. Genesis: Manuscrits-Recherche-Invention, Paris, n. 6, p. 93-106, 1994. Disponível em: http://bit.ly/3jWfNP7. Acesso em: 20 abr. 2020.

GRÉSILLON, A. Nos limites da gênese: da escritura do texto de teatro à encenação. USP Estudos Avançados, São Paulo, v. 9, n. 23, p. 269-285, 1995.

GUILBERT, L. La créativité lexicale. Paris: Librairie Larousse, 1975.

MONTEIRO, J. L. A estilística. São Paulo: Ática, 1991.

OSTROWER, F. Criatividade e processos de criação. 23. ed. Petrópolis: Vozes, 2008.

PIERROT, A. H. Le style en movement, littérature et art. Paris: Belin, 2005. 
REYNAUD, M. J. Metamorfoses da escrita: Húmus de Raul Brandão. Porto: Campo das Letras, 2000.

SALLES, C. A. Redes da criação: construção da obra de arte. 2. ed. Vinhedo, SP: Horizonte, 2006.

WILLEMART, P. Os processos de criação na escritura na arte e na psicanálise. São Paulo: Perspectiva, 2009. 